\title{
The Impact of Foreign Banks' Entry on Profitability of Chinese Commercial Banks
}

\author{
Lingyue Gao ${ }^{\mathrm{a}}$, Yanzhi Lu ${ }^{\mathrm{b}}$, and Qinglin Du ${ }^{\mathrm{c}}$ \\ Shanxi University of Finance and Economics, Shanxi 030000, China \\ adczxglyxhjl@126.com, ${ }^{b} 3047046299 @ q q . c o m,{ }^{c} 584110828 @ q q . c o m$
}

Keywords: Foreign banks, Profitability, Multiple Linear Regression.

\begin{abstract}
In February 2018, the CBCR decided to further open the Chinese banking market and expand the scope of services of foreign banks in China. More research is needed on whether the introduction of foreign banks could stimulate the development of Chinese banking industry or bring in bad influence. The main purpose of a commercial bank is to make a profit, which is the basis of steady operation and expansion. By choosing Cost-Income ratio and Rate of Return on Common Stockholders' Equity as indicators of profitability, external factors and internal factors are analyzed by Multiple Linear Regression, especially the Ratio of Foreign Banks to total assets. According to the results, the government should introduce foreign banks reasonably and rationally further more.
\end{abstract}

\section{Introduction}

Commercial Banks play an important role in Chinese economic development. Efficient banking institutions can promote national economic development through higher profitability.

Until now, the opening of Chinese banking has gone through three stages. After the reform and opening up, China began to bring in foreign bank; the second stage began in 2001, China joint the WTO, gradually lifting restrictions on foreign banks. By the end of 2006, the banking was fully open, allowing foreign banks to provide RMB business services to Chinese customers. In the third stage, China strengthened international supervision of banks after the financial crisis in 2008.

As the international and domestic economic environment tends to be stable, China begins to introduce a series of policies to improve the opening environment of the banking. In February 2018, the CBCR issued a document, which decided to further open the Chinese banking market and expand the scope of services of foreign banks in China.

As for the influence of competitive behavior between foreign banks and the host country, Tressel and Gupta believe that foreign banks only provide capital for good-performance companies, so the domestic banks would be at more risk ${ }^{[1]}$. While Yongjin Gao and Zhaoqiang Ge considered that the entry of foreign banks promoted the formation of the banking industry's competition mechanism, and improved the operating efficiency of China's banking industry ${ }^{[2]}$.

This paper analyzes whether the introduction of foreign capital will stimulate the development of 
domestic banking industry, how the internal and external factors of Chinese commercial Banks affect the profitability of Banks.

\section{Variable Selection}

\subsection{Measure of Profitability}

\subsubsection{Cost-Income Ratio}

It is the ratio of the bank's operating expenses to the operating income, which reflects the cost of the bank's expenditure per unit of income. Commercial banks, especially newly-established banks, small and medium-sized banks, often have cost-income ratio as a representative of operating efficiency, which is the focus of continuous improvement in their daily operations. To obtain the cost-income ratio, simply divide the organization's operating expenses by its operating income for the same period.

\subsubsection{Rate of Return on Common Stockholders' Equity}

It reflects the shareholders' equity returns level, in order to measure the efficiency of companies using their own capital. The rate of return on stock is calculated by dividing a company's net income by the average equity.

\subsection{Factors that Affect Profitability}

\subsubsection{External Factors}

\subsubsection{The Ratio of Foreign Banks to Total Assets}

It's expressed as a percentage of the total assets of foreign banks in Chinese banks. This paper regards it as a indicator to measure the degree of foreign banks' entry.

\subsubsection{GDP Growth Rate}

The gross domestic product (GDP) is one of the primary indicators used to gauge the health of a country's economy. It represents the total of final products and services value of all goods and services produced over a specific time period, often referred to as the size of the economy. Usually, GDP is expressed as a comparison to the previous quarter or year ${ }^{[3]}$.

\subsubsection{Internal Factors}

\subsubsection{Capital Adequacy Ratio}

It is a key indicator of the stability of the business bank, and regulators have a hard requirement for the capital adequacy of the business bank. The capital adequacy ratio is measured by the ratio of the total capital of the core capital and the subsidiary capital to the total risk-weighted assets. 


\subsubsection{Non-performing Loan Ratio}

It measures the effectiveness of a bank in receiving repayments on its loans. The mortgage and interest that the borrower returns on time is the main source of revenue for the banks. If a borrower has not made regular payments at least 90 days, the loan is considered as a non-performing loan. The non-performing loan ratio means, in a bank's loan portfolio, the ratio of the amount of non-performing loans to the total amount of outstanding loans the bank holds ${ }^{[4]}$.

To sum up, the definition and measure of selected variables are shown in the table 1.

Table 1 Definition and measure of each variable

\begin{tabular}{|c|c|c|c|}
\hline \multicolumn{3}{|r|}{ Variable } & Symbol \\
\hline \multirow{2}{*}{\multicolumn{2}{|c|}{ Explained variable }} & Cost - Income Ratio & CIR \\
\hline & & Rate of Return on Common Stockholders' Equity & ROE \\
\hline \multirow{4}{*}{$\begin{array}{l}\text { Explanatory } \\
\text { variable }\end{array}$} & \multirow{2}{*}{ External variable } & The Ratio of Foreign Banks to Total Assets & FBR \\
\hline & & GDP Growth Rate & RGDP \\
\hline & \multirow{2}{*}{ Internal variable } & Capital Adequacy Ratio & CARA \\
\hline & & Non-performing Loan Ratio & NPL \\
\hline
\end{tabular}

\subsection{Data Analysis}

By choosing finance datas of 13 Chinese listed commercial banks( Huaxia Bank, ICBC, Bank of Communications, Bank of China, China Everbright Bank, China Construction Bank, China Minsheng Bank, Agricultural Bank of China, Ping An Bank, Shanghai Pudong Development Bank, Societe Generale Bank, China Merchants Bank, China CITIC Bank), we obtain a time series data from 2007 to 2016. All data are collected from Bankscope database, bank reports and CBRC annual reports. We use time series data and Eviews for modeling and analysis.

\section{Empirical Analysis}

\subsection{Hypotheses Development}

The higher proportion of Foreign Banks's capital in China, Chinese commercial Banks would have a smaller market share and increase their selling expenses. Meanwhile, the entries of foreign banks will force Chinese banks to learn and master advanced financial innovative products from foreign countries with the strong competitive pressure, improve investment efficiency.

According to Danfeng Yu's research, the higher capital adequacy ratio is one of the factors influencing the efficiency which includes the higher cost income ratio ${ }^{[5]}$. But there are less money putted into investment. So, we suppose it has negative effect on rate of equity.

Steady increase in growth rate of GDP could reveal a good economic environment. And it is helpful to increase the income, decrease cost-income ratio. Because of amplification effect of financial leverage, the return on investment income of bank will also rise.

The higher non-performing loan ratio has negative effect on income, so that cost income ratio would be higher. When non-performing loan ratio increase, that is high risk of investment, the return on investment income of bank will decrease.

So, this paper raises the following null hypotheses:

$H_{1}$ : FBR has positive effect on CIR

$H_{2}$ : FBR has positive effect on ROE 
$H_{3}$ : CARA has negative effect on CIR

$H_{4}$ : CARA has negative effect on ROE

$H_{5}$ : RGDP has negative effect on CIR

$H_{6}$ : RGDP has positive effect on ROE

$H_{7}$ : NPL has positive effect on CIR

$H_{8}$ : NPL has negative effect on ROE

\subsection{Multiple Linear Regression}

Suppose that CIR and ROE are related to FBR, RGDP, NPL, CARA with the firm by:

$$
\begin{aligned}
& \mathrm{CIR}=\beta_{0}+\beta_{1} \mathrm{FBR}+\beta_{2} \mathrm{RGDP}+\beta_{3} \mathrm{NPL}+\beta_{4} \mathrm{CARA}+\mathrm{u} \\
& \mathrm{ROE}=\beta_{0}+\beta_{1} \mathrm{FBR}+\beta_{2} \mathrm{RGDP}+\beta_{3} \mathrm{NPL}+\beta_{4} \mathrm{CARA}+\mathrm{u}
\end{aligned}
$$

The regression results are obtained by OLS Regressions using Eviews8.0 software.

$$
\begin{aligned}
& \mathrm{CIR}=81.52+6.89 \mathrm{FBR}-0.97 \mathrm{RGDP}+1.26 \mathrm{NPL}-4.35 \mathrm{CARA} \\
& \mathrm{ROE}=25.45+3.47 \mathrm{FBR}+0.05 \mathrm{RGDP}-3.37 \mathrm{NPL}-0.76 \mathrm{CRAR}
\end{aligned}
$$

According to the test results, we know that except RGDP (T-statistic $=0.18$ ) in equation (4), the absolute value of T-statistic of all parameters is greater than 2. The sixth hypothesis doesn't pass the significance test. So, we drop the RGDP variable in equation (4) and do the OLS regression again. The result is as follow:

$$
\mathrm{ROE}=26.61+3.65 F B R-3.35 \mathrm{NPL}-0.81 \mathrm{CRAR}
$$

The absolute value of T-statistic of all parameters in equation (3) and equation (5) is greater than 2, and the $\mathrm{P}$ value is less than 0.05 , indicating that each explanatory variable has a significant impact on its explained variable when the error rate is less than 0.05 .

\subsection{Test the Model}

Breusch-Godfrey Serial Correlation LM test and White Heteroscedasticity test are performed on the equation (3) and equation (5). According to the test results, equation (3) has serial correlation but equation (5) does not. Meanwhile, neither of them has heteroscedasticity.

\subsection{Modify the Model}

Cochrane-Orcutt iterative method is used to correct equation (3). Add AR (1) and AR (2) to the LS command and use the iterative estimation method to estimate the model. The Durbin-Watson stat. confirms that there is no problem of autocorrelation. Hypothesis1, 2,3,4,5,7 and Hypothesis8 pass the significance test.

The corrected equations are shown in table 2. 
Table 2 The Corrected Equations

\begin{tabular}{c|c|c|c|c|c}
\hline \multicolumn{2}{c|}{ CIR } & \multicolumn{3}{c}{ ROE } \\
\hline Explanatory variable & Coefficient & T-statistic & Explanatory variable & Coefficient & T-statistic \\
\hline FBR & 10.77 & 76.70 & FBR & 3.65 & 4.61 \\
\hline RGDP & -1.70 & -45.77 & & & -3.35 \\
\hline NPL & 1.02 & -22.17 & NPL & -0.81 & -2.49 \\
\hline CARA & -4.49 & -77.08 & CARA & N=10 & $\mathrm{R}^{2}=0.95$ \\
\hline \multicolumn{2}{l|}{$\mathrm{N}=10$} & $\mathrm{R}^{2}=0.99$
\end{tabular}

\section{Conclusions}

FBR has positive effect on ROE and CIR. Foreign banks have boosted the development of local banks because of spillover effects. However, the existence of competition effect makes it more difficult for Chinese commercial banks to operate. For the profitability of China's commercial Banks, the entry of foreign banks is a double-edged sword.

The higher CARA is a positive factor influencing the profitability of China's commercial Banks.

RGDP has negative effect on CIR. Steady increase in growth rate of GDP could reveal a good economic environment which is benefit to profitability of local banks. There is no significant correlation between GDP growth rate and ROE, indicating that the periodicity of the banking industry has not been shown. The main reason is that Chinese policies have a great influence on banks.

The non-performing loan ratio has negative effect on operating income and investment income. Banks will be required to set aside provisions for bad debts from profits, and increase provisions for bad loans will be reducing profits. NPL has a negative impact on profitability.

\section{Suggestions}

At present, the market competition of China's commercial Banks is in the rising stage of 'inverted u'. As foreign Banks play a positive role in promoting the return on net assets of Chinese Banks, China's banking industry needs to further reform and opening up. Meanwhile, it should reduce restrictions on the scope of business for foreign Banks. Introduction of foreign bank reasonably and rationally. At the same time, we should strengthen the cooperation with foreign Banks, using foreign Banks effectively to make a positive contribution to the profitability of China's banking industry.

However, the entry of foreign Banks will increase the operating cost of Chinese banks. We should pay attention to the risk transmission mechanism of foreign Banks and strengthen the prudent risk supervision of foreign Banks ${ }^{[6]}$. Once the risk exceeds the limit, the development of foreign Banks should be restricted and the development of national banking should be protected under the WTO regulations ${ }^{[7]}$.

We should introduce the foreign banks selectively and designedly. At the same time, we should increase the quality of the sales and the intermediary business, and reduce the impact of foreign Banks on the operations of the Chinese bank. Control the cost-income ratio within a reasonable range.

Chinese banks should attach great importance to the problem of non-performing loan. They should not only strengthen the control of risk but also dispose of non-performing loans. And improve the quality of assets so as to better cope with the challenges brought by the entry of foreign Banks.

\section{References}

[1] Thierry Tressel, Poonam Gupta. 2008, Foreign Banks in Poor Countries, Journal of Finance, 5, pp: 2123-2160. [2]Yongjin Gao, Zhaoqiang Ge. 2008, the entry of foreign bank: effect analysis and policy choice, Finance\& Trade Economics, 4, pp: 23-29. 
[3] Yanke Hou. Theory and Empirical Research on the Determinants of Commercial Bank Profitability in China [D]. Shanxi University of Finance \& Economics, 2016.

[4] Xin Zhang. Study on the Factors Affecting the Profitability of Commercial Banks in China [D]. Zhejiang University, 2015.

[5] Danfeng Yu. Research on the impact of capital adequacy ratio on the operating efficiency of Chinese commercial Banks [D]. Liaoning University, 2016.

[6] Teng Ma, Impact of foreign bank entry on Chinese banking performance [D]. Hainan University, 2018.

[7] Guimin Han, Xuemei Yuan, Xuesong Li. The impact of foreign Banks' entry into China on Chinese banking system risks -- based on the robust minimum variance model [J]. Business economics research, 2018(01):165-167. 